\title{
Effect of Partial Substitution of Sodium Chloride with Potassium Chloride on Quality Characteristics of Buffalo Calf Meat Rolls
}

\author{
Surender Kumar*, Sanjay Yadav, Ankita Pal and Vaquil \\ Department of Livestock Products Technology, College of Veterinary Sciences, Lala Lajpat Rai University of Veterinary E Animal \\ Sciences, Hisar, INDIA \\ *Corresponding author: S Kumar; E-mail: hoodas246@gmail.com
}

Received: 15 Dec., 2020

Revised: 12 Jan., 2021

Accepted: 21 Jan., 2021

\begin{abstract}
The study was carried out to develop low salt buffalo calf meat rolls partially substituting sodium chloride with potassium chloride (maintaining equivalent ionic strength) at the levels of $10 \%$ to $50 \%$. Substitution up to $30 \%$ level did not result in any significant variations in sensory attributes but further increase in potassium chloride level caused significant decline in flavor, tenderness, juiciness, texture and overall acceptability. The replacement did not cause any significant difference in proximate composition, water holding capacity, emulsion stability of developed meat rolls. Increase in $\mathrm{pH}$ and decrease in cooking yield values was observed with enhancement in level of potassium chloride but significant effect was noticed only at $50 \%$ replacement. Texture profile and instrumental color of KCL treated rolls were comparable to control. Firmness and toughness declined with increasing incorporation of $\mathrm{KCl}$ but significant impact was noticed only at $50 \%$ level. The replacement up to $30 \%$ was optimum to develop low salt buffalo calf meat rolls.
\end{abstract}

\section{HIGHLIGHTS}

(0 To develop low salt buffalo calf meat rolls partially substituting sodium chloride with potassium chloride.

0 Texture profile and instrumental color of KCL treated rolls were comparable to control.

Keywords: Buffalo calf, low salt, meat rolls, sodium chloride, potassium chloride, sensory quality

India exported 1.23 million tonnes of buffalo meat, worth ₹ 25091 crores in financial year 2018-2019 (APEDA, 2019). Unlike cow, buffalo meat does not have any religious connotations and its slaughter and export is permitted under the Indian laws. It has roughly 2-3 folds cost advantage over mutton and chevon. Even farmers do not consider raising male buffalo calf to be financially rewarding, eventually the country experiences immense loss in respect of elevated mortality rate $(80 \%$ to 84.69 $\%$ ) on account of poor care and managemental practices (Tiwari et al., 2007). In India, buffalo meat is predominantly obtained from slaughter of used up dairy buffaloes at the end of their fruitful life after complete exploitation. The meat so acquired from spent animals is dark, rough and tough in texture and exhibit inferior sensorial and processing attributes (Kandeepan et al., 2009; Naveena et al., 2011). However, these all adversities can be sorted out by utilizing meat of young male buffalo calf below 1.5 years of age. Meat of such calves have greater collagen solubility (Kandeepan et al., 2009) since the collagen cross links get stabilized and the collagen become much less soluble with advancement in age (Maltin et al., 1998). Sodium chloride is the principal ingredient in processed meat due to its preservative properties, capacity to improve taste, flavor and functional attributes to solubilise myofibrillar proteins. Diets high in sodium content have been identified as one of the dietary risk factors for various diseases (Lim et al., 2012). The recommendation of World

How to cite this article: Kumar, S., Yadav, S., Pal, and Vaquil (2021). Effect of partial substitution of sodium chloride with potassium chloride on quality characteristics of buffalo calf meat rolls. J. Anim. Res., 11(1) 119-126.

Source of Support: None; Conflict of Interest: None 
Health Organization (WHO, 2003) suggests that daily salt consumption should not exceed $2 \mathrm{~g}$ /day for general public. Presently, sodium ranks second after calories as the ingredient most looked for by about $65 \%$ of people who read nutritional label of the product before buying (Sloan, 2010).

Total dietary salt intake by Americans is 10 to $12 \mathrm{~g}$ per day (Anon, 1980) and about 33\% of Americans has been diagnosed with high blood pressure, a condition associated with excessive dietary sodium intake (Sloan, 2010). Various researchers have recommended that the partial substitution of sodium chloride with potassium chloride is one of the finest alternatives to alleviate the sodium level in meat products (Lorenzo et al., 2015a; Lorenzo et al., 2015b; Dos Santos et al., 2014; Campagnol et al., 2011). The use of potassium chloride provides an additional benefit as potassium being a counter ion to sodium and diminishes the injurious outcome of sodium on blood pressure and the comparable perceived saltiness can be attained with lower sodium level (Wettasinghe and Shahidi, 1997; Puolanne et al., 1988). So, keeping all these facts in view, an attempt was made to develop low salt buffalo calf meat rolls by partially replacing sodium chloride with potassium chloride.

\section{MATERIALS AND METHODS}

\section{Procurement and processing of raw materials}

Healthy male buffalo calves (10 months of age) reared under similar feeding and managemental conditions were procured from nearby market and slaughtered and dressed as per the standard procedure. The dressed carcasses were washed thoroughly and deboned manually after trimming of visible fat and connective tissue. Deboned meat was packed in colorless low density polyethylene (LDPE) bags at $-18 \pm 2{ }^{\circ} \mathrm{C}$. The frozen chunks were drawn and thawed overnight at $4 \pm 2^{\circ} \mathrm{C}$ and used for development of meat rolls.

Sodium chloride, STPP, sodium nitrite, citric acid, sugar (used in powder form), groundnut oil, bread crumbs powder and eggs were purchased from the local market. Water was used in chilled form. Potassium chloride was procured from reputed firms for use as salt substitute. The condiment mix was prepared by mixing onion and garlic paste (ratio 2:1) and packed in LDPE bags and stored at $-18 \pm 2{ }^{\circ} \mathrm{C}$ till further use.

\section{Preparation of buffalo calf meat rolls}

For preparation of control meat rolls, sodium chloride ( $2 \%)$, sodium tripolyphosphate $(0.5 \%)$, sodium nitrite $(150$ ppm), spice mix (2\%), condiments paste $(3 \%)$, chilled water $(10 \%)$, groundnut oil $(7 \%)$, bread crumbs powder (4\%), whole egg liquid ( $8 \%)$, sugar $(1 \%)$ and citric acid $(0.05 \%)$ were mixed with double minced meat. Stable emulsion was prepared in a meat chopper. The prepared emulsion was stuffed manually in autoclavable beakers and distributed uniformly. The beakers were covered with aluminium foil and steam cooked in a closed container for 35 minutes. After cooking, rolls were taken out and cooled to room temperature, packaged in polythene bags and stored at $4 \pm 2{ }^{\circ} \mathrm{C}$ for further evaluation.

For preparation of low salt meat rolls, sodium chloride was partially substituted with potassium chloride maintaining equivalent ionic strength (IS) to that of $2 \%$ Sodium chloride (0.342). Substitution of $10 \%, 20 \%, 30 \%, 40 \%$ and $50 \%$ of sodium chloride was done with salt substitute.

\section{Analysis}

\section{Ionic Strength}

Ionic strength was calculated as follows:

$$
y=1 / 2 \sum M Z^{2}
$$

Where, $y=$ ionic strength, $M=$ molality, $Z=$ charge on the ion

\section{Sensory quality}

An semi trained panel consisting faculty and research fellows evaluated the meat rolls for the sensory attributes of color and appearance, flavor, texture, tenderness, juiciness and overall acceptability using 8-point descriptive scale (Keeton, 1983), where 8 representing excellent and 1 indicating extremely poor. The warmed test samples were served to the panelists only after assigning the suitable codes. Water was provided for rinsing the mouth between different samples. 


\section{Physicochemical characteristics and proximate composition}

The $\mathrm{pH}$ of meat emulsion and cooked meat rolls was determined following method of Trout et al. (1992). Emulsion stability of control as well as $\mathrm{KCl}$ incorporated $\mathrm{t}$ emulsions was measured using the method of Baliga and Madaiah (1970). WHC (water holding capacity) was determined as per procedure of Wardlaw et al. (1973) with slight modification. Cooking yield was estimated by considering the weight of the cooked meat rolls and initial raw weight and represented as a percentage. Proximate composition was determined by following the standard methods of AOAC (2005).

\section{Texture profile analysis (TPA)}

The textural properties (hardness, springiness, cohesiveness, gumminess and chewiness) of meat rolls were determined by Texture Analyser (TA.HD plus), Stable Micro Systems Ltd., Surrey, England with the Texture Exponent Program. A compression platform of $70 \mathrm{~mm}$ diameter was employed as a probe. The analysis of textured TPA was executed according to the method designed by Bourne (1978). Test samples $\left(2 \mathrm{~cm}^{3}\right.$ size $)$ were compressed to $50 \%$ of their original height. A 5 seconds time was permitted between the two compression cycles. Force time deformation curves were obtained with a $50 \mathrm{~kg}$ load cell used at a cross-head speed of $2 \mathrm{~mm} / \mathrm{s}$.

\section{Shear press value}

The force required to shear a $1 \mathrm{~cm}^{3}$ size sample of meat rolls transversely was determined using Warner-Bratzler shear probe of texture analyser and indicated as firmness $\left(\mathrm{Kg} / \mathrm{cm}^{3}\right)$ and toughness $(\mathrm{Kg}-\mathrm{sec})$.

\section{Instrumental color analysis}

Instrumental color of meat rolls was evaluated using a Konica Minolta chroma meter CR-400 (Konica Minolta Sensing, Inc., Japan) with $8 \mathrm{~mm}$ aperture after calibrating with a white standard plate. Color was represented as CIE Lab, L* (lightness), a* (redness) and b* (yellowness).

\section{RESULTS AND DISCUSSION}

\section{Sensory quality}

No significant difference was noticed in color and appearance scores even up to $50 \%$ substitution of sodium chloride with potassium chloride (by maintaining equivalent ionic strength) in comparison to control meat rolls containing $100 \%$ sodium chloride (Table 1). The flavor scores of control and treated rolls substituting $10 \%$, $20 \%$ and $30 \%$ sodium chloride with potassium chloride were comparable and were more than 7.0 indicating more than very good desirability on 8 point descriptive scale. Further increase in potassium chloride level at $40 \%$ and $50 \%$ resulted in significant decrease in flavor scores. Meat rolls containing $50 \%$ potassium chloride had flavor scores of 5.67 indicating less than moderate acceptability. Alves et al. (2017) also observed that replacement of $50 \%$ sodium chloride with potassium chloride resulted in slightly diminished salty taste and a little bitter, astringent and metallic flavor in reduced fat low salt bologna type sausages.

Table 1: Effect of partial replacement of sodium chloride with potassium chloride on sensory scores of buffalo calf meat rolls $($ Mean $\pm \mathrm{SD})(\mathrm{n}=12)$

\begin{tabular}{|c|c|c|c|c|c|c|}
\hline Treatments & $\begin{array}{l}\text { Color and } \\
\text { Appearance }\end{array}$ & Flavor & Texture & Juiciness & Tenderness & OAA \\
\hline Control $\mathrm{NaCl}(100 \%)$ & $7.83^{a} \pm 0.33$ & $7.83^{a} \pm 0.39$ & $7.83^{\mathrm{a}} \pm 0.33$ & $7.88^{a} \pm 0.31$ & $7.88^{\mathrm{a}} \pm 0.31$ & $7.83^{a} \pm 0.39$ \\
\hline $\mathrm{NaCl}+\mathrm{KCl}(90 \%+10 \%)$ & $7.83^{\mathrm{a}} \pm 0.39$ & $7.83^{\mathrm{a}} \pm 0.33$ & $7.75^{\mathrm{a}} \pm 0.45$ & $7.83^{\mathrm{a}} \pm 0.39$ & $7.79^{\mathrm{a}} \pm 0.40$ & $7.79^{a} \pm 0.40$ \\
\hline $\mathrm{NaCl}+\mathrm{KCl}(80 \%+20 \%)$ & $7.79^{\mathrm{a}} \pm 0.40$ & $7.71^{\mathrm{a}} \pm 0.40$ & $7.71^{\mathrm{a}} \pm 0.45$ & $7.75^{\mathrm{a}} \pm 0.45$ & $7.71^{\mathrm{a}} \pm 0.45$ & $7.71^{\mathrm{a}} \pm 0.45$ \\
\hline $\mathrm{NaCl}+\mathrm{KCl}(70 \%+30 \%)$ & $7.75^{\mathrm{a}} \pm 0.45$ & $7.46^{\mathrm{a}} \pm 0.50$ & $7.50^{\mathrm{ab}} \pm 0.52$ & $7.46^{\mathrm{ab}} \pm 0.45$ & $7.58^{\mathrm{ab}} \pm 0.51$ & $7.54^{\mathrm{a}} \pm 0.50$ \\
\hline $\mathrm{NaCl}+\mathrm{KCl}(60 \%+40 \%)$ & $7.75^{\mathrm{a}} \pm 0.40$ & $6.73^{b} \pm 0.45$ & $7.08^{b c} \pm 0.36$ & $7.13^{b c} \pm 0.31$ & $7.17^{\mathrm{bc}} \pm 0.39$ & $6.88^{b} \pm 0.43$ \\
\hline $\mathrm{NaCl}+\mathrm{KCl}(50 \%+50 \%)$ & $7.71^{\mathrm{a}} \pm 0.45$ & $5.67^{c} \pm 0.49$ & $6.88^{c} \pm 0.31$ & $6.83^{c} \pm 0.39$ & $6.96^{c} \pm 0.33$ & $5.96^{c} \pm 0.33$ \\
\hline
\end{tabular}

Means with different superscripts in a column differ significantly $(\mathrm{P} \leq 0.05)$. 
The scores for texture, juiciness and tenderness were also comparable up to $30 \%$ substitution. Further substitution of Sodium chloride with potassium chloride at $40 \%$ and $50 \%$ resulted in significant decline in texture, juiciness and tenderness scores. Bidlas and Lambert (2008) reported that partial replacement of sodium chloride with potassium chloride generally had adverse effect on flavor and texture of the meat products.

The overall acceptability score was highest for control which decreased with each substitution level but did not significantly declined up to $30 \%$ replacement. Overall acceptability scores reduced significantly at $40 \%$ and 50 $\%$ levels in comparison to control which might be due to decline in scores of flavor and other sensory attributes at these levels of replacement. The mean overall acceptability score was around 6.0 at $50 \%$ level of replacement which indicates moderate acceptable on 8 point descriptive scale. Replacement of sodium chloride with potassium chloride beyond a certain limit results in sensory denial which is attributed to perception of bitter and metallic taste (Dos Santos et al., 2014; Lorenzo et al., 2015b).

\section{Physico-chemical characteristics}

No significant difference was noticed in the $\mathrm{pH}$ of raw emulsion among control, $10 \%, 20 \%, 30 \%$ and $40 \%$ replacement level but $\mathrm{pH}$ was significantly elevated when $50 \%$ of sodium chloride was substituted with potassium chloride (Table 2). The results were in accordance with findings of Alves et al. (2017) who reported that substitution of sodium chloride with potassium chloride resulted in significantly higher $\mathrm{pH}$ as compared to the control. Horita et al. (2011) also noticed significantly higher $\mathrm{pH}$ readings in mortadella sausages with $50 \%$ substitution of sodium chloride with potassium chloride. The $\mathrm{pH}$ values of cooked meat rolls also demonstrated similar trend. There was increase in $\mathrm{pH}$ after cooking which was because of increase in salt level owing to deprivation of moisture and alteration in net charge due to denaturation of proteins on cooking (Babu et al., 1994). Nath et al. (1996) noticed 0.3 to 0.4 units increase in $\mathrm{pH}$ after cooking.

No significant difference in WHC was observed between control and substituted samples although a decreasing trend with increased potassium chloride level was noticed. The results were in conformance with findings of Gimeno et al. (1998) who revealed that there was no significant change in WHC after substitution of sodium chloride with a mixture of sodium chloride, potassium chloride, $\mathrm{MgCl}_{2}$ and $\mathrm{CaCl}_{2}$ at equivalent ionic strength to that of control.

Emulsion stability also gradually decreased with increasing substitution level but no significant effect was noticed between control and treated rolls. Alves et al. (2017) also observed no significant differences in percent water and fat release among the treatments when sodium chloride was replaced by potassium chloride in low fat bologna type sausages.

Cooking yield also declined with enhancement in potassium chloride level in treated rolls and significant decrease in comparison to control was noticed at $50 \%$ incorporation. This might be due to marginal decrease in water holding capacity and emulsion stability which resulted in significant decrease in cooking yield at highest level of substitution. Substitution of sodium chloride with potassium chloride at $50 \%$ level did not result in significant differences in cooking loss in comparison to

Table 2: Effect of partial replacement of sodium chloride with potassium chloride on physico-chemical properties of emulsion and buffalo calf meat rolls (Mean $\pm \mathrm{SD})(\mathrm{n}=6)$

\begin{tabular}{|c|c|c|c|c|c|}
\hline Treatments & $\begin{array}{l}\mathrm{pH} \\
\text { (Raw emulsion) }\end{array}$ & $\begin{array}{l}\mathrm{pH} \\
\text { (Cooked) }\end{array}$ & $\begin{array}{l}\text { Water holding } \\
\text { capacity (\%) }\end{array}$ & $\begin{array}{l}\text { Emulsion stability } \\
(\%)\end{array}$ & $\begin{array}{l}\text { Cooking Yield } \\
(\%)\end{array}$ \\
\hline Control $\mathrm{NaCl}(100 \%)$ & $5.98^{\mathrm{b}} \pm 0.05$ & $6.11^{\mathrm{b}} \pm 0.06$ & $42.78^{a} \pm 2.33$ & $79.90^{\mathrm{a}} \pm 0.87$ & $85.07^{\mathrm{a}} \pm 1.34$ \\
\hline $\mathrm{NaCl}+\mathrm{KCl}(90 \%+10 \%)$ & $5.99^{b} \pm 0.07$ & $6.14^{\mathrm{ab}} \pm 0.06$ & $42.34^{\mathrm{a}} \pm 2.34$ & $79.75^{\mathrm{a}} \pm 1.03$ & $84.94^{\mathrm{a}} \pm 1.37$ \\
\hline $\mathrm{NaCl}+\mathrm{KCl}(80 \%+20 \%)$ & $6.01^{\mathrm{ab}} \pm 0.06$ & $6.15^{\mathrm{ab}} \pm 0.07$ & $41.78^{\mathrm{a}} \pm 2.45$ & $79.73^{\mathrm{a}} \pm 1.06$ & $84.76^{\mathrm{a}} \pm 1.45$ \\
\hline $\mathrm{NaCl}+\mathrm{KCl}(70 \%+30 \%)$ & $6.03^{\mathrm{ab}} \pm 0.03$ & $6.18^{\mathrm{ab}} \pm 0.04$ & $40.89^{\mathrm{a}} \pm 2.62$ & $79.58^{\mathrm{a}} \pm 0.90$ & $84.12^{\mathrm{ab}} \pm 1.34$ \\
\hline $\mathrm{NaCl}+\mathrm{KCl}(60 \%+40 \%)$ & $6.06^{\mathrm{ab}} \pm 0.03$ & $6.20^{\mathrm{ab}} \pm 0.04$ & $39.83^{\mathrm{a}} \pm 2.63$ & $79.10^{\mathrm{a}} \pm 1.22$ & $83.39^{\mathrm{ab}} \pm 1.24$ \\
\hline $\mathrm{NaCl}+\mathrm{KCl}(50 \%+50 \%)$ & $6.09^{\mathrm{a}} \pm 0.04$ & $6.23^{\mathrm{a}} \pm 0.06$ & $38.73^{\mathrm{a}} \pm 2.54$ & $78.42^{\mathrm{a}} \pm 1.02$ & $82.23^{b} \pm 1.42$ \\
\hline
\end{tabular}

Means with different superscripts in a column differ significantly $(\mathrm{P} \leq 0.05)$. 
control samples (Alves et al., 2017). Choi et al. (2014) also indicated no significant impact on cooking loss or moisture content of the low sodium frankfurter sausages when $40 \%$ sodium chloride was replaced by potassium chloride or combination of potassium lactate and calcium ascorbate. Pietrasik and Gaudette (2015) concluded that ionic strength and not the type of ions play vital role in preserving protein extraction ability and moisture retention potential. Reduction of sodium chloride up to $25 \%$ level did not affect the yield and purge loss of frankfurters during storage (Tobin et al., 2013).

\section{Proximate composition}

Replacement of sodium chloride with potassium chloride did not influence the moisture content of meat rolls significantly (Table 3 ). No significant difference was noticed in the protein content of control and salt substituted samples. Fat and ash content did not vary significantly among control and treatments and increasing level of potassium chloride did not cause any significant impact on fat and ash content of meat rolls. No significant change in proximate attributes might be due to similar composition of emulsion and no effect of substitution of sodium chloride with potassium chloride. The findings of proximate composition were in accordance with Alves et al. (2017) who depicted that replacement of sodium chloride with potassium chloride did not significantly alter moisture, protein, ether extract and ash content of low fat bologna type sausages. Horita et al. (2011) formulated low fat bologna sausages by partially replacing sodium chloride with other chloride salts and did not observe any difference in proximate composition.

\section{Texture profile analysis}

No significant difference in hardness was observed between control and treatments although a decreasing trend in hardness with increased $\mathrm{KCl}$ level was noticed (Table 4). Springiness is the ability of the sample to recover its original form after a deforming force is removed whereas cohesiveness is the extent to which sample

Table 3: Effect of partial replacement of sodium chloride with potassium chloride on proximate composition of buffalo calf meat rolls $($ Mean \pm SD) $(n=6)$

\begin{tabular}{|c|c|c|c|c|}
\hline Treatments & Moisture (\%) & Protein (\%) & Fat $(\%)$ & $\operatorname{Ash}(\%)$ \\
\hline Control $\mathrm{NaCl}(100 \%)$ & $64.27^{\mathrm{a}} \pm 0.51$ & $19.42^{\mathrm{a}} \pm 0.70$ & $7.72^{a} \pm 0.48$ & $2.95^{\mathrm{a}} \pm 0.32$ \\
\hline $\mathrm{NaCl}+\mathrm{KCl}(90 \%+10 \%)$ & $63.97^{\mathrm{a}} \pm 0.93$ & $19.67^{\mathrm{a}} \pm 0.60$ & $7.33^{\mathrm{a}} \pm 0.93$ & $3.01^{\mathrm{a}} \pm 0.26$ \\
\hline $\mathrm{NaCl}+\mathrm{KCl}(80 \%+20 \%)$ & $63.99^{\mathrm{a}} \pm 0.92$ & $19.50^{\mathrm{a}} \pm 0.55$ & $7.54^{\mathrm{a}} \pm 0.67$ & $2.96^{\mathrm{a}} \pm 0.33$ \\
\hline $\mathrm{NaCl}+\mathrm{KCl}(70 \%+30 \%)$ & $64.15^{\mathrm{a}} \pm 0.89$ & $19.18^{\mathrm{a}} \pm 0.72$ & $7.42^{\mathrm{a}} \pm 0.74$ & $2.90^{\mathrm{a}} \pm 0.23$ \\
\hline $\mathrm{NaCl}+\mathrm{KCl}(60 \%+40 \%)$ & $63.70^{\mathrm{a}} \pm 0.82$ & $19.45^{\mathrm{a}} \pm 0.81$ & $7.52^{\mathrm{a}} \pm 0.80$ & $2.99^{a} \pm 0.26$ \\
\hline $\mathrm{NaCl}+\mathrm{KCl}(50 \%+50 \%)$ & $63.83 \pm 1.05$ & $19.46^{\mathrm{a}} \pm 0.57$ & $7.54^{\mathrm{a}} \pm 0.74$ & $2.93^{\mathrm{a}} \pm 0.35$ \\
\hline
\end{tabular}

Means with different superscripts in a column differ significantly $(\mathrm{P} \leq 0.05)$.

Table 4: Effect of partial replacement of sodium chloride with potassium chloride on texture profile of buffalo calf meat rolls $($ Mean $\pm \mathrm{SD})(\mathrm{n}=6)$

\begin{tabular}{|c|c|c|c|c|c|}
\hline Treatments & Hardness (N) & Springiness & Cohesiveness & Gumminess (N) & Chewiness $(\mathbf{N})$ \\
\hline Control NaCl (100 \%) & $43.63^{a} \pm 4.46$ & $0.85^{\mathrm{a}} \pm 0.02$ & $0.62^{\mathrm{a}} \pm 0.08$ & $26.59^{a} \pm 2.16$ & $22.56^{\mathrm{a}} \pm 1.97$ \\
\hline $\mathrm{NaCl}+\mathrm{KCl}(90 \%+10 \%)$ & $43.42^{\mathrm{a}} \pm 3.75$ & $0.84^{\mathrm{a}} \pm 0.04$ & $0.61^{\mathrm{a}} \pm 0.04$ & $26.65^{\mathrm{a}} \pm 3.89$ & $22.27^{\mathrm{a}} \pm 3.25$ \\
\hline $\mathrm{NaCl}+\mathrm{KCl}(80 \%+20 \%)$ & $42.38^{a} \pm 3.09$ & $0.85^{\mathrm{a}} \pm 0.04$ & $0.66^{\mathrm{a}} \pm 0.06$ & $27.98^{a} \pm 3.92$ & $23.90^{\mathrm{a}} \pm 4.35$ \\
\hline $\mathrm{NaCl}+\mathrm{KCl}(70 \%+30 \%)$ & $41.15^{\mathrm{a}} \pm 3.46$ & $0.86^{\mathrm{a}} \pm 0.03$ & $0.69^{\mathrm{a}} \pm 0.05$ & $28.33^{\mathrm{a}} \pm 3.20$ & $24.51^{\mathrm{a}} \pm 3.41$ \\
\hline $\mathrm{NaCl}+\mathrm{KCl}(60 \%+40 \%)$ & $39.85^{\mathrm{a}} \pm 3.27$ & $0.82^{\mathrm{a}} \pm 0.05$ & $0.61^{\mathrm{a}} \pm 0.07$ & $24.04^{\mathrm{a}} \pm 2.23$ & $19.77^{\mathrm{a}} \pm 2.28$ \\
\hline $\mathrm{NaCl}+\mathrm{KCl}(50 \%+50 \%)$ & $37.83^{\mathrm{a}} \pm 2.81$ & $0.84^{\mathrm{a}} \pm 0.03$ & $0.67^{\mathrm{a}} \pm 0.06$ & $25.38^{\mathrm{a}} \pm 1.58$ & $21.43^{\mathrm{a}} \pm 1.90$ \\
\hline
\end{tabular}

Means with different superscripts in a column differ significantly $(\mathrm{P} \leq 0.05)$; N- Newton. 
can be deformed prior to rupture. Both springiness and cohesiveness were comparable for control and $\mathrm{KCl}$ treated meat rolls. The gumminess and chewiness values were also comparable for control and $\mathrm{KCl}$ treated meat rolls. Results of instrumental texture profile showed that replacement of $\mathrm{NaCl}$ with $\mathrm{KCl}$ (maintaining equivalent ionic strength) did not have any significant negative influence on the textural attributes of the cooked meat rolls. These findings were in agreement with those reported by Alves et al. (2017) who observed that $50 \%$ substitution of $\mathrm{NaCl}$ with $\mathrm{KCl}$ did not alter significantly the readings of hardness, springiness, cohesiveness, gumminess and chewiness of bologna type sausages with respect to control.

Similarly, Horita et al. (2011) noticed no significant difference in hardness values of emulsified mortadella when $50 \%$ of $\mathrm{NaCl}$ was substituted with $\mathrm{KCl}$. Choi et al. (2014) reported that frankfurter sausages containing $\mathrm{NaCl}$ upto $60 \%$ of control had similar hardness, springiness, cohesiveness and chewiness values as control sample. The springiness of bologna type sausages did not show significant changes between the control and salt substituted sample (Yang et al., 2007). The texture of the product relies on the structure and integrity of the protein matrix developed during cooking and lowering or substituting $\mathrm{NaCl}$ content with other salt in the sausages resulted in softer texture as compared to control (Pietrasik and Gaudette, 2015).

\section{Firmness and toughness}

Replacement of $\mathrm{NaCl}$ with $\mathrm{KCl}$ up to $40 \%$ level did not result in any significant effect on firmness and toughness of meat rolls although a decreasing trend for firmness and toughness was noticed (Table 5). Further replacement of $\mathrm{NaCl}$ with $\mathrm{KCl}$ to $50 \%$ level resulted in significant decrease in firmness and toughness values of meat rolls. Hand et al. (1982) reported that substitution of $\mathrm{NaCl}$ with $100 \% \mathrm{KCl}$ or $\mathrm{MgCl}_{2}$ significantly decreased the firmness of turkey frankfurters but $35 \%$ substitution did not affect firmness significantly.

Table 5: Effect of partial replacement of sodium chloride with potassium chloride on firmness $\left(\mathrm{Kg} / \mathrm{cm}^{3}\right)$ and toughness $(\mathrm{Kg}$-sec) of buffalo calf meat rolls $($ Mean $\pm \mathrm{SD})(\mathrm{n}=6)$

\begin{tabular}{lll}
\hline Treatments & Firmness $\left(\mathbf{K g} / \mathbf{c m}^{\mathbf{3}}\right)$ & Toughness $($ Kg-sec) \\
\hline Control $\mathrm{NaCl}(100 \%)$ & $0.94^{\mathrm{a}} \pm 0.03$ & $10.42^{\mathrm{a}} \pm 0.33$ \\
$\mathrm{NaCl}+\mathrm{KCl}(90 \%+10 \%)$ & $0.94^{\mathrm{a}} \pm 0.06$ & $10.39^{\mathrm{a}} \pm 0.36$ \\
$\mathrm{NaCl}+\mathrm{KCl}(80 \%+20 \%)$ & $0.93^{\mathrm{ab}} \pm 0.11$ & $10.21^{\mathrm{ab}} \pm 0.20$ \\
$\mathrm{NaCl}+\mathrm{KCl}(70 \%+30 \%)$ & $0.91^{\mathrm{ab}} \pm 0.07$ & $10.11^{\mathrm{ab}} \pm 0.15$ \\
$\mathrm{NaCl}+\mathrm{KCl}(60 \%+40 \%)$ & $0.89^{\mathrm{ab}} \pm 0.05$ & $9.98^{\mathrm{ab}} \pm 0.22$ \\
$\mathrm{NaCl}+\mathrm{KCl}(50 \%+50 \%)$ & $0.82^{\mathrm{b}} \pm 0.11$ & $9.87^{\mathrm{b}} \pm 0.36$ \\
\hline
\end{tabular}

Means with different superscripts in a column differ significantly $(\mathrm{P} \leq 0.05)$.

Table 6: Effect of partial replacement of sodium chloride with potassium chloride on instrumental color values of buffalo calf meat rolls $($ Mean $\pm \mathrm{SD})(\mathrm{n}=12)$

\begin{tabular}{llll}
\hline Treatment & $\mathbf{L}^{*}$ (lightness) & $\mathbf{a}^{*}$ (redness) & b* (yellowness) $^{\mathrm{a}}$ \\
\hline $\mathrm{Control} \mathrm{NaCl}(100 \%)$ & $62.40^{\mathrm{a}} \pm 0.88$ & $9.14^{\mathrm{a}} \pm 0.39$ & $16.54^{\mathrm{a}} \pm 0.48$ \\
$\mathrm{NaCl}+\mathrm{KCl}(90 \%+10 \%)$ & $62.03^{\mathrm{a}} \pm 0.84$ & $9.36^{\mathrm{a}} \pm 0.43$ & $16.20^{\mathrm{a}} \pm 0.45$ \\
$\mathrm{NaCl}+\mathrm{KCl}(80 \%+20 \%)$ & $62.19^{\mathrm{a}} \pm 0.77$ & $9.25^{\mathrm{a}} \pm 0.48$ & $16.27^{\mathrm{a}} \pm 0.47$ \\
$\mathrm{NaCl}+\mathrm{KCl}(70 \%+30 \%)$ & $61.74^{\mathrm{a}} \pm 0.94$ & $9.43^{\mathrm{a}} \pm 0.44$ & $16.44^{\mathrm{a}} \pm 0.50$ \\
$\mathrm{NaCl}+\mathrm{KCl}(60 \%+40 \%)$ & $61.68^{\mathrm{a}} \pm 0.86$ & $9.50^{\mathrm{a}} \pm 0.49$ & $16.49^{\mathrm{a}} \pm 0.42$ \\
$\mathrm{NaCl}+\mathrm{KCl}(50 \%+50 \%)$ & $62.27^{\mathrm{a}} \pm 0.75$ & $9.28^{\mathrm{a}} \pm 0.42$ & $16.35^{\mathrm{a}} \pm 0.39$ \\
\hline
\end{tabular}

Means with different superscripts in a column differ significantly $(\mathrm{P} \leq 0.05)$. 


\section{Instrumental Color}

The L* (lightness) values did not change significantly with substitution of $\mathrm{NaCl}$ with $\mathrm{KCl}$. Similarly no significant effect was observed on $\mathrm{a}^{*}$ (redness) and $\mathrm{b}^{*}$ (yellowness) values. The results revealed that substitution of $\mathrm{NaCl}$ with either $\mathrm{KCl}$ did not impart any negative influence on instrumental color values of buffalo calf meat rolls.

The results were in conformance with the findings of Horita et al. (2011) who observed no significant difference in instrumental color values of emulsified mortadella sausages when $50 \%$ of $\mathrm{NaCl}$ was substituted with $\mathrm{KCl}$. The $50 \%$ substitution of $\mathrm{NaCl}$ with $\mathrm{KCl}$ did not alter significantly readings of $\mathrm{L}^{*}, \mathrm{a}^{*}$ and $\mathrm{b}^{*}$ of bologna type sausages (Alves et al., 2017).

\section{CONCLUSION}

The study revealed that replacement of sodium chloride up to $30 \%$ did not result in any significant variation in sensory quality but further increase in potassium chloride level caused significant decline in sensory quality buffalo calf meat rolls. Partial substitution did not result in any significant variation in proximate composition, water holding capacity and emulsion stability, instrumental texture profile and color. Increase in $\mathrm{pH}$ and decrease in cooking yield, firmness and toughness values was observed with enhancement in level of potassium chloride but significant effect was noticed only at $50 \%$ replacement. It was concluded that buffalo calf meat rolls replacing 30 $\%$ sodium chloride with potassium chloride (maintaining equivalent ionic strength) were comparable with control in terms of sensory quality, physico-chemical properties, proximate composition and instrumental attributes.

\section{ACKNOWLEDGEMENTS}

The authors are thankful to Head of Department, Department of Livestock Products Technology, College of Veterinary Sciences, Lala Lajpat Rai University of Veterinary \& Animal Sciences, Hisar for providing necessary facilities.

\section{REFERENCES}

Alves, L.A.A.D.S., Lorenzo, J.M., Goncalves, C.A.A., Santos, B.A.D., Heck, R.T., Cichoski, A.J. and Campagnol, P.C.B. 2017. Impact of lysine and liquid smoke as flavor enhancers on the quality of low-fat Bologna-type sausages with $50 \%$ replacement of $\mathrm{NaCl}$ by KCl. Meat Sci., 123: $50-56$.

Anon. 1980. Dietary salt, a scientific status summary by the institute of Food Technologists expert panel on food safety and nutrition and the committee on public information. Food Technol., 34(1): 85-91.

AOAC. 2005. Official Methods of Analysis, $16^{\text {th }}$ edition, Association of Official Analytical Chemists, Washington, DC.

APEDA. 2019. Agricultural and Processed Food Products Export Development Authority. http://agriexchange.apeda. gov.in/indexp/exportstatemen t.aspx.

Babu, N.P., Kowale, B.N., Rao, V.K. and Bisht, G.S. 1994. Effect of cooking and storage on lipid oxidation and development of cholesterol oxides in chicken meat. Ind. J. Poult. Sci., 29: 254-262.

Baliga, B.R., and Madaiah, N. 1970. Quality of sausage emulsion prepared from mutton. J. Food Sci., 35(4): 383-385.

Bidlas, E. and Lambert, R.J.W. 2008. Comparing the antimicrobial effectiveness of $\mathrm{NaCl}$ and $\mathrm{KCl}$ with a view to salt/sodium replacement. Int. J. Food Microbiol., 124(1): 98102.

Bourne, M.C. 1978. Texture profile analysis. Food Technol., 33: $62-62,72$.

Campagnol, P.C.B., Dos-Santos, B.A., Morgano, M.A., Terra, N.N. and Pollonio, M.A.R. 2011. Application of lysine, taurine, disodium inosinate and disodium guanylate in fermented cooked sausages with $50 \%$ replacement of $\mathrm{NaCl}$ by KCl. Meat Sci., 87(3): 239-243.

Choi, Y.M., Jung, K.C., Jo, H.M., Nam, K.W., Choe, J.H., Rhee, M.S. and Kim, B.C. 2014. Combined effects of potassium lactate and calcium ascorbate as sodium chloride substitutes on the physicochemical and sensory characteristics of lowsodium frankfurter sausage. Meat Sci., 96(1): 21-25.

Dos Santos, B.A., Bastianello Campagnol, P.C., Da Cruz, A.G., Galvao, M.T.E.L., Monteiro, R.A., Wagner, R. and Pollonio, M.A.R. 2014. Check all that apply and free listing to describe the sensory characteristics of low sodium dry fermented sausages: Comparison with trained panel. Food Res. Int., 76: 725-734.

Gimeno, O., Astiasaran, I. and Bello, J. 1998. A mixture of potassium, magnesium and calcium chlorides as a partial replacement of sodium chloride in dry fermented sausages. $J$. Agric. Food Chem., 46(10): 4372-4375.

Hand, L.W., Terrell, R.N. and Smith G.C. 1982. Effect of complete or partial replacement of sodium chloride on processing and sensory properties of hams. J. Food Sci., 47: 1776-1778, 1782.

Horita, C.N., Morgano, M.A., Celeghini, R.M.S. and Pollonio, M.A.R. 2011. Physico-chemical and sensory properties of 
reduced-fat mortadella prepared with blends of calcium, magnesium and potassium chloride as partial substitutes for sodium chloride. Meat Sci., 89(4): 426-433.

Kandeepan, G., Anjaneyulu, A.S.R., Kondaiah, N., Mendiratta, S.K. and Lakshmanan, V. 2009. Effect of age and gender on the processing characteristics of buffalo meat. Meat Sci., 83(1): 10-14.

Keeton, J.T. 1983. Effect of fat, $\mathrm{NaCl}$ and phosphate levels on the chemical and sensory properties of pork patties. J. Food Sci., 48: 878-881.

Lim, S.S., Vos, T., Flaxman, A.D., Danaei, G., Shibuya, K., Adair, R.H. and Memish, Z.A. 2012. A comparative risk assessment of burden of disease and injury attributable to 67 risk factors and risk factor clusters in 21 regions, 1990-2010: A systematic analysis for the global burden of disease study, 2012. The Lancet, 380(9859): 2224-2260.

Lorenzo, J.M., Bermudez, R., Dominguez, R., Guiotto, A., Franco, D. and Purrinos, L. 2015a. Physicochemical and microbial changes during the manufacturing process of drycured lacón salted with potassium, calcium and magnesium chloride as a partial replacement for sodium chloride. Food Control, 50: 763-769.

Lorenzo, J.M., Cittadini, A., Bermudez, R., Munekata, P.E. and Dominguez, R. 2015b. Influence of partial replacement of $\mathrm{NaCl}$ with $\mathrm{KCl}, \mathrm{CaCl}_{2}$ and $\mathrm{MgCl}_{2}$ on proteolysis, lipolysis and sensory properties during the manufacture of dry-cured lacon. Food Control, 55: 90-96.

Maltin, C.A., Sinclair, K.D., Warriss, P.D., Grant, C.M., Porter, A.D. and Delday, M.I. 1998. The effects of age at slaughter, genotype and finishing system on the biochemical properties, muscle fibre type characteristics and eating quality of bull beef from suckled calves. Anim. Sci. J., 66(2): 341-348.

Nath, R.L., Mahapatra, C.M., Kondiah, N. and Singh, J.N. 1996. Quality of chicken meat patties as influenced by microwave and conventional oven cooking. J. Food Sci. Technol., 33(2): 162-164.

Naveena, B.M., Sen, A.R., Muthukumar, M., Babji, Y. and Kondaiah, N. 2011. Effects of salt and ammonium hydroxide on the quality of ground buffalo meat. Meat Sci., 87: 315320 .
Pietrasik, Z. and Gaudette, N.J. 2015. The effect of salt replacers and flavor enhancer on the processing characteristics and consumer acceptance of Turkey sausages. J. Sci. Food Agric., 95(9): 1845-1851.

Puolanne, E., Saarela, E. and Ruusunen, M. 1988. The effect of $\mathrm{NaCl}-\mathrm{KCl}-\mathrm{MgSO}_{4}$-mixture (Pan) on the quality of cooked sausage. In Proceedings of the 34th international congress of meat science and technology. Part B (pp. 302-304). Brisbane, Australia.

Sloan, A.E. 2010. Top 10 functional food trends. Food Technol., 64(4): 22.

Tiwari, R., Sharma, M.C. and Singh, B.P. 2007. Buffalo calf health care in commercial dairy farms: a field study in Uttar Pradesh (India). Livest. Res. Rural., 19(3): 38.

Tobin, B.D., O'Sullivan, M.G., Hamill, R.M. and Kerry, J.P. 2013. The impact of salt and fat level variation on the physiochemical properties and sensory quality of pork breakfast sausages. Meat Sci., 93(2): 145-152.

Trout, E.S., Hunt, M.C., Johson, D.E., Clans, J.R., Castner, C.L. and Kroff, D.H. 1992. Characteristics of low fat ground beef containing texture modifying ingredients. J. Food Sci., 57: 19-24.

Wardlaw, F.R., McCaskill, L.H. and Acton, J.C. 1973. Effects of postmortem changes on poultry meat loaf properties. J. Food Sci., 38: 421-423.

Wettasinghe, M. and Shahidi, F. 1997. Oxidative stability, cooking yield and texture of pork treated with a low-sodium salt. J. Muscle Foods, 8: 373-382.

WHO (world health organization). 2003. Diet, nutrition and the prevention of chronic diseases. WHO Technical Report Series 916. Geneva, World Health Organization.

Yang, H.S., Choi, S.G., Jeon, J.T., Park, G.B. and Joo, S.T. 2007. Textural and sensory properties of low fat pork sausages with added hydrated oatmeal and tofu as texture modifying agents. Meat Sci., 75(2): 283-289. 